\title{
Radost v pojetí J. A. Komenského Miriam Prokešová
}

DOI: $10.32725 /$ cetv.2021.035

\section{Abstrakt:}

Hovoříme-li o životě Jana Amose Komenského, jen málokdy jej spojujeme s radostí. Známe jej naopak jako člověka, který se ve svém životě potýkal s mnoha vpravdě neradostnými situacemi. Komenský však ve svých dílech často radost v různých podobách (laetitia, gaudium, voluptas, hilaritas) zmiňuje. Je patrné, že ji vnímá jako životní postoj, ze kterého můžeme a máme ve svých životech čerpat. Je to nejen radost ze vzdělání, ale především radost z Boha, která dodává člověku v jeho strastech a bolestech tolik potřebnou naději. V následující stati se doslova "ponoříme" do Komenského myšlenek a slov, které tento jeho životní postoj vystihují. Půjdeme po stopách Komenského díla, pátrajíce po jeho pojetí radosti, která je i v současné době a pro náš život tolik potřebná. Stat' je zpracována na základě připravovaného hesla Radost pro dílo Encyclopaedia Comeniana, které si vyžadovalo důkladné prostudování Komenského díla převážně v edici DJAK (Dílo Jana Amose Komenského, Praha: Academia, 1969-) a vyhledávání tohoto pojmu v Komenského spisech převážně v českém a latinském jazyce. Ne vždy - vzhledem k dostupnosti textů v českém jazyce - je citováno z tohoto díla; čerpáno je rovněž z dalších vydání Komenského díla, což je uvedeno v poznámkách pod čarou.

Klíčová slova: radost, veselost, utěšení; trojí rozkoš duše, radost ze vzdělání, radost z Boha

„... Měj hlásné srdce, tichý jazyk...

Odejdiž již, milý můj,

a stůj v losu svém až do skonání svého: užívaje potěšení, $k$ němuž jsem tě privivedl, s radostí."

O životě Jana Amose Komenského hovoříme jako o životě plném bolesti a životních ztrát. Jako kdyby radost téměř nepoznal. Velice brzy osiřel, byl vyrván z rodinného prostředí svých čtyř sester, později po studiích jeho štastné fulnecké období s první ženou Magdalenou a dvěma dětmi končí nutností jeho skrývání se a posléze smrtí ženy i dětí. ${ }^{2}$ Komenský to ve svém díle

1 Jan Amos KOMENSKÝ, Labyrint světa a ráj srdce, Opera omnia, Dílo Jana Amose Komenského - Johannis Amos Comenii opera omnia, Praha: Academia, sv. 3 (dále jen DJAK 3), 1978, (s. 265-412), zde s. 395, kapitola LIII. K vydání připravil Jaroslav Kolár.

2 Předpokládá se, že tzv. fulnecké období v životě J. A. Komenského patřilo k jeho nejštastnějším v životě. Víme, že z Fulneku odchází v druhé polovině prosince roku 1621, do podzimu 1622 se ukrývá na Moravě, možná i v Přerově. Na jaře 1622 zemřela jeho žena i děti, avšak neví se, zda se se svým druhým dítětem, které patrně zemřelo krátce po narození, vůbec kdy setkal. Taktéž není historicky 
O sirobě $(1622,1624)$ komentuje slovy, že „... člověk mrtvou téměř v živém těle duši nosí... “3 V témže roce 1623, rok po smrti ženy a dětí, začíná psát proslulý Labyrint světa a lufthaus/ráj srdce. A slova $\mathrm{v}$ závěru tohoto díla jsou vzhledem $\mathrm{k}$ jeho vlastním životním osudům (nehledě na to, co jej v životě ještě potká) takřkka ohromující. Píše tam, zde již v mottu tohoto článku uváděná slova, odkazující na to, že máme stát $\mathrm{v}$ losu svém, tedy v čemkoliv, co nás $\mathrm{v}$ životě potká, $\mathrm{v}$ potěšení, $\mathrm{s}$ radostí, a to nejen po určitou chvíli, ale až do skonání svého. ${ }^{4}$ Stůjme tedy ve svém životním losu a vše přijímejme, a nejen přijímejme, užívejme si to, žijme s radostí! Pojd’me tímto světem, na své životní pouti a přes všechna neštěstí, bolesti, ztráty, slzy s radostí přijímejme nejen to krásné, štastné, veselé, ale i všechno z té druhé stránky životního spektra. At’ nás potká cokoliv, radujme se.

Toto hovoří člověk, který ve svém životě zažil plno neštěstí, bolestí, útrap, a to jak v soukromém, tak i ve svém profesním životě. Prožil nejen bolest ze ztráty rodičů ve věku, kdy již tuto ztrátu mohl vnímat, bolest ze ztráty ženy a dětí, bolest z pronásledování a bolest ze ztráty rodné vlasti. Věděl také o pálení svých knih ve Fulneku před svým odchodem do exilu, o nějakých přibližně třicet let později byl v Lešně svědkem ohně, který ničil a zničil jeho dílo. Umírá mu i druhá žena a zůstává na své malé děti sám, možná i proto se opět žení se ženou o třicet let mladší. Na své životní pouti je na mnoha místech vítán s otevřenou náručí, ale kolikrát odchází provázen nepochopením a nedorozuměním. Jeho život je neustále jako na houpačce (kolotoči), kde však starosti a bolest, zdá se, převládají. Sám k tomu o sobě v závěru úvodního věnování svého díla Via lucis (1641-1642, 1668) patrně s jistým povzdechem píše: „Comenius senex, cujus vita defecit in doloribus et anni in gemitibus. "

Čím tedy byla pro samotného Komenského radost, o které se zmiňuje i v době, kdy v sobě jeho vlastními slovy mrtvou téměř v živém těle duši nosil? Jak ji vnímal ve svých dílech, jak se o ní vyjadřoval v průběhu let ve svých spisech? Pojem radost se vine Komenského spisy téměř jako červená nit. Nacházíme jej pod různými termíny, nejčastěji v latinském laetitia, gaudium, voluptas, hilaritas a mnohými dalšími.

Zamysleme se nejprve, jak bychom mohli radost všeobecně charakterizovat.

\section{Pojetí radosti}

Radost je psychický stav člověka, ve kterém proživáme pocit potěšení a procitujeme štěstí. Jinými slovy, radost je něčím více, než vyjadřuje momentálně často používaný termín well-being, což je subjektivní pocit pohody. Radost není statický pojem, ale má řadu stupňů. Může být prožívána bud' jen na úrovni smyslového uspokojení (např. radost z tělesného zdraví, radost z krásných scenérií př́rody či uměleckého, architektonického díla, při poslechu hudby atp.). Radost má však i rovinu duševní a duchovní. Na těchto dvou úrovních mưže být chápána jako hybná síla života, spojena s láskou jako životním principem a jako jedním ze základních předpokladů života.

Radost (v pojetí autora tohoto článku) není chápána pouze jako pomíjivý okamžik, momentální záblesk, ztrácející se v minulosti. Není to ani krátkodobá pomíjivá emoce, která plyne z uspokojení

doloženo pohlaví obou Komenského dětí z tohoto prvního manželství.

3 Jan Amos KOMENSKÝ, O sirobě, Opera omnia, (DJAK 3), Praha: Academia, sv. 3, 1978, (s. 427-472), zde s. 434. K vydání připravil Milan Kopecký. Dílo vzniká v průběhu let 1622, vydáno poprvé v roce 1624. „A vpravdě, když člověk dobrého přítele ztratí, teprve mu to obyčejně, co na něm měl a co s ním ztratil, na mysl jde: odkudž toužení, tesknost, svírání, pláč a naříkání, zalévání očí slzami a srdce krví, prahnutí a svadnutí kostí pochází, že člověk mrtvou téměř v živém těle duši nosí.“

4 Jan Amos KOMENSKÝ, Labyrint světa a ráj srdce, Opera omnia, DJAK 3, Praha: Academia, sv. 3, 1978, (s. 265-412), zde s. 395, kapitola LIII. K vydání připravil Jaroslav Kolár.

5 Jan Amos KOMENSKÝ, Via lucis, Opera omnia, Dílo Jana Amose Komenského - Johannis Amos Comenii opera omnia, Praha: Academia, sv. 14 (dále jen DJAK 14), 1974, (s. 279-385), zde s. 292. Editor Jarmila Borská, Julie Nováková. Český překlad dle J. KOPECKÝ a kol., Via lucis, Praha: SPN, 1961: „Jeden z pokorných mužů tužeb, Stařec Komenský, jehož život uplynul v bolesti a léta v žalu.“ 
potřeb. Radost není jen letmý okamžik štěstí bez delšího trvání. Radost je naopak trvalý životní pocit, který se ukládá do hloubky našeho nitra a stává se životním postojem; nadhledem nad životními strádáními a útrapami. Stává se štítem, který chrání rozbolavělou duši a srdce před zoufalstvím a nicotou. Radost je štítem proti úzkosti a jako taková nás nese životem.

\subsection{Pojetí radosti u Komenského}

Hledáme-li odpověd' na otázku, čím byla radost pro samotného Komenského, nahlédněme do jeho díla.

Ve spisku $O$ sirobě (1624) si uvědomuje, že na světě nic věčného není, a tam, kde je radost, přichází často i žal. Žádné potěšení zde na světě není stálé. Ve smrti svých rodičů nakonec vidí i to dobré pro něj samotného, když v 10. kapitole nazvané $O$ dítkách osiřalých píše, že „... více a častěji dítkám smrt rodičů k dobrému než ke zlému bývá... "6 V první kapitole tohoto dílka sděluje, že „Všecko to, na čemž sobě jakýmkoli způsobem lidé v světě potěšení zakládají, tu má povahu, že i radost s sebou, i žalost přináší. Radost, dokud se užívati dává: žalost, když odchází. Nebo poněvadž na zemi nic věčného není, než všecko jedno za druhým jde a míjí, nemưže také žádné zdejší potěšení stálé býti, byt' i dlouhé bylo. “7

Jan Amos Komenský spojoval radost s různými stavy člověka. Opakem radosti pak byla obava, strach, hrůza, děs. Radost však spojoval také se zármutkem a bolestí, jak vidíme ve výše citovaném spisku O sirobě. Žádné potěšení na světě není stálé. Tak, jak píše v úvodu Centrum securitatis (1633):

„Svět jest kolo, jenž se točí,

prudce chvěje, hlučí, zvučí.

Kdo mu v centrum neusedne,

zamotá se a vypadne. ${ }^{\text {"8 }}$

U Komenského je radost stavem, který působí nejen smyslové veselí a potěšení. Radost je u něj spojena i s vưlí. Souznívá tak u Komenského s pojetím člověka jako celku, s jeho tělesným, duševním i duchovním vývojem. Radost není vnímána staticky, ale stupňovitě a vrcholí v rovině duchovní, ve spojení s Bohem a seho dílem, moudrostí a láskou. Stupňovitost pojetí radosti se v díle Komenského projevila i způsobem vyjádření, užitím určitých výrazů latinských nebo českých, které jsou variantami, popř́padě stupni radosti.

Přibližme si nejprve stě̌̌ejní termíny, které Komenský pro výraz radost používal či definoval. Tak lze nejprve srovnat základní učebnici Komenského Janua linguarum reserata $(1631)^{9}$ a její českou variantu Dvére jazyků otevřené $(1633)^{10}$, obojí kap. XXIX, $\$ 366$. V latině užil Komenský tato slova: hilaritas, laetitia, gaudium, voluptas (juncta tamen metui); a slovesně: laetari, gaudere, oblectare. Ve Dvérích jazyků..., kap. XXIX, O vưli a náruživostech, píše tato slova: „... Jest tu? Jásá

6 Jan Amos KOMENSKÝ, O sirobè, Opera omnia (DJAK 3), Praha: Academia, sv. 3, 1978, (s. 427-468), zde s. 449. Kapitola X. O dítkách osiřalých: „... že více a častěji dítkám smrt rodičů k dobrému nežli ke zlému bývá; život naproti tomu ke škodě víc než k užitku.“

7 Jan Amos KOMENSKÝ, O sirobě, kap. I., Co a jak těžká věc jest siroba?, Opera omnia (DJAK 3), 1978, s. 433.

8 Jan Amos KOMENSKÝ, Centrum securitatis, to jest Hlubina bezpečnosti, Opera omnia, Dílo Jana Amose Komenského - Johannis Amos Comenii opera omnia, Praha: Academia, sv. 3, (dále jen DJAK 3), 1978, (s. 473-564), zde s. 477. Překlad z poznámky pod čarou. K vydání připravili Květa Neradová a Martin Steiner.

9 Jan Amos KOMENSKÝ, Janua linguarum reserata, Opera omnia, Dílo Jana Amose Komenského - Johannis Amos Comenii opera omnia, Praha: Academia, 1986, (dále jen DJAK 15/I), (s. 269-301). Editoři: Marie Kyralová, Martin Steiner.

10 Jan Amos KOMENSKÝ, Dvére jazyků odevřené, Opera omnia, Dílo Jana Amose Komenského - Johannis Amos Comenii opera omnia, Praha: Academia, sv. 11, (dále jen DJAK 11), 1973, (s. 359-435), zde s. 387. K vydání připravil Karel Hádek. 
chtivostí, těší se, raduje se, obveseluje se (kochá se), použiváním jeho, ztratiti se boje; odkudž veselost, utěšení, rádost, rozkoš, spojená však s bázní. "'11 $\mathrm{V}$ českém jazyce používá výrazy: veselost, utěšení (potěšení), radost, větš̌ radost, rozkoš (spojená však s bázní); a slovesně: jásat chtivostí, těšit se, radovat se, obveselovat se (kochat se).

V Pansofickém slovníku (Lexicon reale pansophicum) ${ }^{12}$ najdeme pojmy laetitia, laetari, oblectare; gaudium, gaudere; hilaritas, jucunditas, voluptas; deliciae. ${ }^{13}$

Zaměřme se na bližší vymezení těchto pojmů tak, jak je chápal sám Komenský.

- Výraz laetitia je nejobecnější termín pro radost, radostné reagování na vítané, vytoužené věci, které jsou dobré; laetari zahrnovalo projev radosti, uživání dobré věci s radostí. Příbuzné slovo oblectare znamená působit radost připomenutím vítané, vytoužené věci ve smyslu být potěšen, potěšit.

- Výraz gaudium je vyjádřením větší, hlubší radosti (laetitia profundior), kdy někdo kypí radostí, radostí se mu chvěje srdce, obrazně poskočí si, jásá radostí, je naplněn radostí.

- Vnějškově projevovanou radost pomocí smyslů pojmenovává Komenský jako hilaritas. Jinými slovy jde o vyjádření veselí, veselosti (definice je jen u hilaris jako radost projevovaná smyslem, pohybem rukou, tělem). Podobně jucunditas je smyslově projevovaná radost.

- Výraz voluptas pak označuje reakci na př́ijemné věci; znamená rozkoš z toho „být dobrým“ a těšit se $z$ nejvyšš́ho dobra.

- Výraz deliciae pak značí rozkoš, vrcholné potěšení.

Z tohoto malého výčtu vidíme, že skutečně v Komenského pojetí (a v latinském i českém jazyce) není radost jako radost, že toto slovo má různé konotace a tím i ne zcela totožný význam.

\subsection{Radost jako trojí rozkoš duše (voluptas animae) dle Komenského}

Na radost můžeme dle J. A. Komenského pohlížet také jako na radost, vyvěrající z trojí rozkoše duše. Jak si toto pojetí přibližit? Pokusíme se o to v následujících rádcích, opírajících se o texty v Komenského Didaktice a Velké didaktice. Jakým způsobem zde Komenský radost pojímá? V X. kapitole české Didaktiky ${ }^{14}$ (1633) a její latinské verze Didactica magna ${ }^{15}$ rozlišil Komenský tři stupně radosti, tři stupně rozkoše (voluptas). Vysvětlil, že rozkoší nemyslí jakoukoli nestřídmost „... kterouž bláznivá hloupost lidská rozkoší nazývá “"16, která kazí zdraví, způsobuje bolest, nemoc i smrt, nýbrž ji chápe jako rozkoš duše (voluptas animae), která je trojí, přičemž záleží na jejím původu. „Duše trojí míti může rozkoš, jednu v věcech všelijakých vůkol sebe; druhou v sobě, třetí v Bohu. ${ }^{\text {"17 }}$

Trojí původ radosti vysvětluje Komenský následujícím způsobem: radost pochází za prvé bud'

11 Jan Amos KOMENSKÝ, Dvére jazyků odevřené, Opera omnia, DJAK 11, 1973, Praha: Academia, s. 387.

12 Podle Lenky Řezníkové a Vladimíra Urbánka zpracovával Komenský tento Pansofický slovník v letech 1662-1665. In: Lenka ŘEZNÍKOVÁ - Vladimír URBÁNEK, Ex definitione. Pansofické pojmy J. A. Komenského a jejich dobové kontexty, Praha: Filosofia, 2018.

13 Lexicon reale pansophicum. In: Vlasta Tatjana MIŠKOVSKÁ, Archiv pro bádání o životě a díle Jana Amose Komenského, Acta Comeniana 1/1959, s. 41-51.

14 Jan Amos KOMENSKÝ, Didactica, Opera omnia, Dílo Jana Amose Komenského - Johannis Amos Comenii opera omnia, Praha: Academia, sv. 11 (dále jen DJAK 11), 1973, (s. 33-221), zde s. 74-75; 110-112. K vydání připravil Stanislav Králík.

15 Jan Amos KOMENSKÝ, Didactica magna, Opera omnia, Dílo Jana Amose Komenského - Johannis Amos Comenii opera omnia, Praha: Academia, sv. 15/I (dále jen DJAK 15/I), 1986, (s. 29-209). Editoři: Vojtěch Balík, Marie Kyralová, Stanislav Sousedík.

16 KOMENSKÝ, Didactica..., s. 74.

17 KOMENSKÝ, Didactica..., s. 74. 
$z$ věcí, z jejich poznávání a zkoumání, což přináší potěšení a radost z bystření rozumu (jak dosvědčuje i biblická Kniha moudrosti 8,16). Za druhé radost pochází $z$ nás samých, když pozorujeme, jak chápeme řád světa, řád spravedlnosti, a že jeho plnění přináší člověku „vnitřní spořádanost“, a to v závislosti na tom, jak se rozvíjejí lidské ctnosti a dobré svědomí. A za třetí Komenský rozlišuje nejvyšší stupeň rozkoše, vrcholnou radost. Tato radost pochází $z$ Boha, z pocitu, že člověk získává milost Boží a plesá v jeho otcovské přízni a rozplývá se láskou $\mathrm{k}$ Bohu.

\subsection{Radost (rozkoš) ze vzdělání v pojetí Komenského}

S nejvyšším stupněm voluptas animae (rozkoš duše) souvisí také radost ze vzdělání, ctnosti a zbožnosti, tedy eruditio, virtus, pietas, jinak dle Komenského slov v Didaktice: „... tři studnice, z nichž všickni nejdokonalejších rozkoší pramenové plně tekou. " ${ }^{18}$ Tyto tři studnice - vzdělání, ctnost a zbožnost, které člověku přinášejí vnitřní spořádanost, mají naplňovat jednotlivce i školy, všechny lidi, a to ve všem, co je pro život podstatné. Později, v Pampaedii, ve čtvrtém dílu Obecné porady o nápravě věcí lidských (Consultatio de rerum humanarum emendatione catholica, 1644-1670), ${ }^{19}$ tuto rozkoš Komenský nazýval i slovem deliciae (potěšení), světlo mysli jako hortus deliciarum, obrazně řečeno jako světlo potěšení, „zahradu rozkoší, zahradu radostí‘.

Skutečnost, že je radost spjata s výchovou a vzděláváním, a tím také i s různými požadavky a principy, vidíme již v Komenského Informatoriu školy mateřské (1632). V tomto díle Komenský spojuje radost s láskou. Doporučuje zde rodičům rozveselovat děti vyprávěním, zpěvem, hudbou: „... poněvadž dobrá mysl pưl zdraví jest, nýbrž dle Sirachova vysvědčení veselé srdce sám život člověka jest; ... mají také rodičové obmýšleti, aby dítky jejich $\mathrm{v}$ veselosti a potěšení nedostatku nesná-

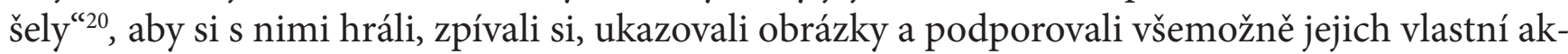
tivitu, což vše posiluje i zdraví dětí. „Čím víc toho uměti budou, tím se jim to víc líbiti bude. ${ }^{{ }^{21}} \mathrm{Ve}$ Škole dětství (Schola infantiae) ${ }^{22}$ v Pampaedii používá Komenský výrazů hilaris, laetitia, oblectatio a doposud nezmiňovaný výraz placere (těšit, potěšit) a opět cituje knihu Sírachovcovu (Sír 30,23). Poznávání, vzdělávání a tím vzrůstající moudrost by měla být nejen př́ičinou vnitřní spořádanosti, ale rovněž př́ičinou potěšení a radosti. O tomto píše Komenský už v předmluvě spisu Theatrum universitatis rerum $(1616-1618,1627$ ?): „Není trpký byt moudrosti ani bolestné bydlení s ní, ale potěšené a radostné. " 23

Fakt, že radost a potěšení spojuje se vzděláváním a výchovou, je patrný z již jmenované Didaktiky (Didactica) i Obecné porady o nápravě věcí lidských. Vzdělávání by mělo být snadné díky dobrým, odpovídajícím metodám, vedoucím ke kultuře rozumu, vůle, citu, schopností a užívání života, aby se lidé stávali moudrými a blaženými (Didactica, Velká didaktika, kap. XVII, Fundamentum II). Radost v souvislosti s dobrým vzděláním můžeme najít i v díle Gentis felicitas (Štěstí národa) $(1654)^{24}$, kde vzdělávací aktivita, moudrost, svornost a mír pro celý národ přináší „radostný zdar“

18 KOMENSKÝ, Didactica..., s. 74.

19 Problém vzniku, geneze a osudů tohoto Komenského díla, které zůstalo nedokončeno, vizte v pojednání Vojtěch BALÍK - Věra SCHIFFEROVÁ, Ưvod k Obecné poradě, in: DJAK 19/I, 2014, Praha: Academia, s. 21-34.

20 Jan Amos KOMENSKÝ, Informatorium školy mateřské, Opera omnia, Dílo Jana Amose Komenského - Johannis Amos Comenii opera omnia, Praha: Academia, sv. 11, (dále jen DJAK 11), 1973, (s. 223-275), zde s. 243. K vydání připravila Dagmar Čapková.

21 KOMENSKÝ, Informatorium..., s. 249.

22 Jan Amos KOMENSKÝ, Vševýchova. Pampaedia, Praha: Státní nakladatelství, 1948, s. 136-186. Kap. IX. Škola dětství. Klín mateřský, čili o prozíravé výchově lidského pokolení od narození až asi k šestému roku věku. Přeložil Josef Hendrich.

23 Jan Amos KOMENSKÝ, Theatrum universitatis rerum, Opera omnia, Dílo Jana Amose Komenského - Johannis Amos Comenii opera omnia, Praha: Academia, sv. 1 (dále jen: DJAK 1), 1969, (s. 95-181), zde s. 104. K vydání připravili Jiří Daňhelka, Karel Hádek, Antonín Škarka.

24 Jan Amos KOMENSKÝ, Gentis Felicitas, Opera omnia, Dílo Jana Amose Komenského - Johannis Amos Comenii opera omnia, Praha: Academia, sv. 13 (dále jen DJAK 13), 1972, (s. 35-66), zde s. 41. K vydání př́ipravila Julie Nováková, Martin Steiner. „Štastný je tedy 
(laetitia). „Felix ergo gens quae scholis bonis et libris bonis et circa juventutis educationem institutis aut consuetudinibus bonis abundat."

Jak by se lidská mysl mohla stát onou zahradou radosti (rozkoší), bude-li správně vzdělána, přibližuje Komenský ve své Pampaedii. V kap. III. ${ }^{25}$ pojednává o obsahu pansofického vzdělávání vedoucího k dovršování podstaty lidství. Jeden z požadavků je: „... způsobit, aby se lidé radovali nad svými dary, bezpečni jsouce před neštěstím “ (zlem). Jak si Komenský představoval metodu vedoucí k tomuto vzdělání, vyložil např. v VII. kap., $\$ 26$ : „Lidská přirozenost je uzpůsobena tak, že smysly, rozum, vůle i všechny schopnosti hledají ustavičně přiměřenou stravu. Odpíráš-li ji, rmoutí se, ochabují, vadnou, hynou. Jestliže ji prozíravě dodáváš, radují se, osvěžují se, oživují a stačí na všechno..."26 (V latinské verzi použil Komenský slovesa gaudere a laetari).

\subsection{Radost z Boha v pojetí Komenského}

Nejčastěji však dával Jan Amos Komenský radost do souvislosti s dobrem, pravdou, svobodou, jednotou, láskou. Metaforické pojetí světla jako radostného několikerého osvícení (fyzikálního, duševního i duchovního) uváděl Komenský do souvislosti s nápravnou aktivitou, s pravdou, láskou a nadějí na uskutečnění univerzální nápravy všech-všeho-veskrze. Je to patrné v Obecné poradě o nápravě věcí lidských, a to už v prvních dvou dílech, Panegersii a Panaugii. Např. ve IV. kap., $\$ 10$ Panegersie je vyjádřena radost $\mathrm{z}$ ustavičného tvoření (v lat. znění voluptas): „Lidská přičinlivost nepokládá za vhodné pro sebe samu předem skládat ruce v klín. A tak ze všeho hned vytváří zas něco jiného a ničemu nedopřeje konce, protože ji svádí pokušení jakési ustavičné radosti z tvoření..." ${ }^{27}$ Toto je motivem k sepsání Obecné nápravy, jak zdůvodňuje sám Komenský: „Naším záměrem je ukázat s boží milostí lidstvu, v čem je jeho veškeré dobro, upozornit, jak jsme jeho hranice překročili a bloudili nesčetnými zpơsoby po nicotnostech, a naznačit konečně spolehlivé, pohodlné a radostné cesty $\mathrm{k}$ dávné prostotě, klidu a štěstí. "28

Komenský si uchovává naději, jak je zřejmé např. z kap. VIII, $\$ 13$, ve které píše, že „všechna přirozenost se vyhýbá bolesti a těší se z lásky, a tak je naděje, že až budou objeveny spolehlivé základy pravé jednoty (a tedy pravdy a pokoje), všichni s radostí (cum gaudio) přiskočí a vzájemnou nenávist ochotně zamění za vzájemnou lásku. ${ }^{\text {"29 }}$

Také v Panaugii uvedl Komenský radost (gaudere) do souvislosti s touhou po nápravě věcí. V Pansofii (Pansophia), Světě možném (Mundus possibilis) je zdůrazněn význam světla mysli (hortus deliciarum) pro pochopení věcí, s nimiž se člověk ve světě setká, a člověk se má z toho radovat (gaudere). „Viděl jsi v sobě světlo své mysli? Poznal jsi, že nebylo do tebe vloženo z žádných knih mimo tebe, ani že jsem je do tebe nevlil já, nýbrž že do tebe vtéká právě z tvé mysli? Máš z toho radost? Raduj se z toho, nebot budeš mít sám v sobě otevřený pramen, prýštící uvnitř tebe, tekoucí stále, aniž by ochaboval, který tě bude provázet po celý život..." ${ }^{30}$

národ, který oplývá dobrými školami, dobrými knihami a ve výchově mládeže dobrými tradicemi a zvyky“ (volný překlad autorky článku). Česky rovněž In: Vybrané spisy Komenského, (VSK) VI., Praha: SPN, 1972, s. 261.

25 Jan Amos KOMENSKÝ, Vševýchova. Pampaedia, Kap. třetí. „Co znamená, že člověk má býti vzděláván ve všem, co dovršuje podstatu lidství, proč je to nutné a jaká je té věci možnost i snadnost“, Praha: Státní nakladatelství, 1948, s. 39-74. Přeložil Josef Hendrich.

26 Jan Amos KOMENSKÝ, Vševýchova. Pampaedia, Kap. sedmá. V̌̌eučitelství. To jest o universálních vzdělavatelích, učitelích vševědných, znalých učit všechny všemu všestranně; jak veliká je jejich nutnost a jaké podmínky, Praha: Státní nakladatelství, 1948, s. 102-131. Přeložil Josef Hendrich.

27 Jan Amos KOMENSKÝ, Obecná porada o nápravě věcí lidských, in: Panegersia, Praha: Academia, 1992, s. 81. Překlad Jan Kalivoda, Martin Svatoš

28 KOMENSKÝ, Obecná porada..., s. 75.

29 KOMENSKÝ, Obecná porada..., s. 104.

30 Jan Amos KOMENSKÝ, Obecná porada, In: Pansofia, překlad Martin Steiner, Jaromír Červenka, Markéta Klosová, 1992 , s. 291. 
V Pansofii, Světě materiálním (Mundus materialis), dal Komenský v kap. VII, která pojednává o člověku, uživateli světa kolem nás, do souvislosti vnímání věci krásné či potřebné, milé s dobrem, všeobecnou láskou k oné věci, zahrnující potěšení (oblectatio) a touhu, snahu ji získat; pokud jsou prostředky, vzniká naděje a z ní radost (laetitia) a podněty pro další horlivost; z dosažení pramení hlubší radost (gaudium) z toho, že jsme se jí zmocnili, rozkoš (voluptas), rozlévající se libost ducha (jucunditas animi). ${ }^{31}$

V Panorthosii, ${ }^{32} \mathrm{v}$ kapitole o nápravě škol (kap. XXIV), spojuje Komenský radost ze vzdělání s radostí z Boha. Zde navrhuje „zahradu utěšené podívané “ („paradisus deliciarum") jako součást nápravy světské správy. V kap. XXV je zmíněna radost (gaudium perfectum) z př́pravy lidí na nebeské království, která by byla úkolem zvláštní vysoké školy, k níž přispěje nová filosofie, nová politika a nová teologie jako součást všenápravy.

Avšak největší a nejčastěji vyjadřovaná radost byla u Komenského radost z Boha, radost zbožných lidí, radost spojovaná s nadějí na spásu. V Historii o těžkých protivenstvích je tato radost líčena v kap. LX o 27 českých mučednících, popravených r. 1621 v Praze z rozkazu císaře Ferdinanda II.: „... Již nám této hodiny pomine žalost vezdejší a nastane radost nová, srdečná a věčná... “33 Radost spojená s Bohem, dárcem radosti se často objevuje v Komenského přebásnění Žalmů (1633, např. v IX, XIX, XX, XXI, XXVIII, XXXII, XXXV, XLI, XLIII.). Můžeme uvést např. závěr Žalmu XXXII: „Plésejtež tedy v Hospodinu všickni vy pobožní! V komkoli upř́mé34 jest srdce, radujte se v Pánu!“"35 nebo Žalm IX: „Ó soudce můj spravedlivý, vyvedls při mou a soud pravý: radost, radost $\mathrm{v}$ samém tobě pokládá srdce mé sobě. “36

Tak již v Přemyšlování o dokonalosti křestanské37 (1622) vyvolená duše zbožně rozjímá a nemůže než radostí slzet, jak by si přála láskou se odvděčit Bohu za jeho dobrodiní, zejména za vnitřní pokoj a radost $\mathrm{v}$ duchu. Dokonalost křestanská obsahuje lásku, snášenlivost, dobrotu, skromnost atp. a veselí i dokonalé utěšení, radost $\mathrm{v}$ duchu, $\mathrm{v}$ nebi rozkoše. $\mathrm{V}$ druhé části Labyrintu (tedy v Ráji srdce), kde vnitřní světlo zbožných křestanů, svoboda srdcí oddaných Bohu, láska k Bohu i bližnímu přináší radost, ba rozkoš, radost větší, než je pouze radost světa; život je radostné plesání v Bohu, vrcholící potěšením spasení. Podobně se vyskytuje radost ve Světě duchovním (Mundus spiritualis) v Pansofii ${ }^{38}$, kde je popsána cesta $\mathrm{k}$ dokonalosti pro nápravu všeho-ve všem-veskrze, např. $\mathrm{v}$ kap. I život $\mathrm{v}$ Bohu jako láska a radost (amor et gaudium) nebo $\mathrm{v}$ kap. VII je jedním ze sedmi stupňu znovuzrození radost (gaudium) z Krista Spasitele. V závěrečné části Pansofie, kap. X, Jubileus jubileorum ${ }^{39}$ je znamením vrcholu lidské moudrosti trvalé světlo mysli, trvalé radostné srdce (svavitates cordis perpetuae), vrchol štěstí (felicitatis culmen).

Toto - chvála Hospodina, život zasvěcený v radosti z Boha a Bohu, trvalé radostné srdce jako vrchol štěstí, to bylo hybnou silou Komenského veškerého počínání. Píše o tom již na počátku své

31 KOMENSKÝ, Obecná porada..., s. 487.

32 Jan Amos KOMENSKÝ, Obecná porada, sv. III., 1992, In: Panorthosia, s. 384, 413, 425, (s. 253-462).

33 Jan Amos KOMENSKÝ, Historie o těžkých protivenstvích, Opera omnia, Dílo Jana Amose Komenského - Johannis Amos Comenii opera omnia, Praha: Academia, sv. 9 (dále jen DJAK 9), 1989 (s. 49-198), zde s. 123. K vydání připravili Amedeo Molnár, Věra Petráčková, Zuzana Pospíšilová, Noemi Rejchrtová.

34 Jan Amos KOMENSKÝ, Žalmy, Opera omnia, Dílo Jana Amose Komenského - Johannis Amos Comenii opera omnia, Praha: Academia, sv. 4 (dále jen DJAK 4), 1983, Žalmy (s. 215-290), zde s. 246. Upř́mé srdce - originál v DJAK. K vydání připravil Milan Kopecký, Antonín Škarka.

35 KOMENSKÝ, Žalmy..., s. 246.

36 KOMENSKÝ, Žalmy..., s. 223.

37 Jan Amos KOMENSKÝ, Přemyšlování o dokonalosti křestanské, Opera omnia, Dílo Jana Amose Komenského - Johannis Amos Comenii opera omnia, Praha: Academia, 1978, sv. 3 (DJAK 3), zvl. kap. III-XII a závěr, s. 185-233. K vydání připravili Jarmila Koschinová, Stanislav Králík, Květa Neradová, Noemi Rejchrtová.

39 KOMENSKÝ, Obecná porada..., s. 490-491. 
profesní i životní dráhy v Theatrum universitatis rerum (1616-1618), kde i celý svůj budoucí život předesílá slovy, ve kterých Boha ještě s mladickým údivem oslovuje poněkud neobvykle a zvláštně: „... předivný Pane Bože. $\mathrm{V}$ Tvém jménu to začínám i v témž jménu tvém konati a dokonati míním, sebe i všecko toto tobě v ochranu odevzdávaje... "40 Tato slova vyjadřují, v čem spočíval největší impuls Komenského života, jeho aktivit i schopnosti znovu povstávat ze svých pádů k vrcholné aktivitě. Na otázku, jak Komenský přemáhal svou bolest a žal, utrpení, onu téměř mrtvou $d u s ̌ i$, kterou po veškerých životních ranách ve svém živém těle nosil, můžeme odpovědět rovněž slovy proroka Nehemiáše ze Starého zákona, kterého Komenský rád citoval: „Radost Hospodinova budiž síla vaše" (Neh 8,10$)$.

Jan Amos Komenský o této síle radosti nejen psal, ale on ji skutečně ve svém životě procitoval a žil. Byla jeho hortus deliciarum. „Pobožní mají stálou v srdci radost.“" "Nebo kde Bůh jest, tu nebe; kde nebe, tu radost věčná: kde radost věčná, tu člověk neví, čeho víc žádati. Stín jest žert, smích, všeliká světa radost proti radosti této... " ${ }^{22}$ Vždyt již ve vzpomínaném Labyrintu světa a ráji srdce hovoří Komenský takto: „V světě zajisté všudy slepotu a mrákotu, tuto jasné světlo jsem spatřil; v světě šalbu, tuto pravdu; v světě neřádů plno, tuto sám ušlechtilý řád; v světě kvaltování, tuto pokoj; v světě starosti a fresuňky, tuto radost; v světě nedostatky, tuto hojnost; v světě otroctví a porobu, tuto svobodu; v světě vše nesnadné a těžké, tuto vše lehké; v světě žalostné odevšad př́hody, tuto samu bezpečnost..." 43

\section{Závěr}

Pojetí Komenského radosti je v dosavadní literatuře vztahující se k jeho dílu i životu oblast doposud, dá se říci, neprobádaná. A přitom je zřejmé, že pro něj tento pojem, a hlavně konkrétní prožívání oné radosti, nebylo zcela cizí. Přes útrapy života a bolesti, které nepochybně zažíval, byl člověkem neutuchající víry, naplněn radostí z Boha, která mu dodávala životní sílu, s níž dokázal překonávat vše těžké a nedobré, s čím se v životě potkával.

Jak je však patrné z tohoto článku, Komenského pojetí radosti se nevztahuje jen k Bohu samotnému, ale sám Komenský ji vnímá z různých možných úhlů pohledů, týkajících se emočních stavů člověka samotného. Vymezuje radost výrazy, jakými jsou např. laetitia, gaudium, hilaritas, voluptas, deliciae, lišícími se od sebe nejen možným výrazem a projevem, ale také hloubkou prožívání. Ve svém díle (např. ve Dveřích jazyků odevřených, v Pansofickém slovníku, ale i jinde) jednotlivé pojetí radosti vymezuje. V Didactice a v Didactice magně chápe radost jako trojí rozkoš duše - voluptas animae. Ta je pak rozlišena na základě svého původu (zdroje) jako radost z věcí (vnější), radost vyvěrající z nás samých (možno nazvat radost vnitřní, radost duše) a vrcholná radost pocházející ze samotného Boha.

V Komenského pojetí najdeme také radost, která se vztahuje ke vzdělání, k poznání jako takovému. Tato radost je spojena se ctností a zbožností (eruditio, virtus, pietas). Toto trojí nám přináší přímo zahradu rozkoší, zahradu radosti, ono Komenského hortus deliciarum. Vidíme to nejen v Obecné poradě o nápravě věcí lidských, ale také již např. v Informatoriu školy mateřské, v Theatrum univesitatis rerum, v didaktikách, v Gentis Felicitas a jinde.

Vrcholnou radostí je pak pro Komenského radost z Boha samotného. V částech Obecné porady o nápravě věcí lidských, v Panegersii a Panaugii, je tato radost cestou k původní prostotě, klidu

40 KOMENSKÝ, Theatrum..., s. 100.

41 KOMENSKÝ, Labyrint světa..., s. 390. Jde o název kapitoly XLIX.

42 KOMENSKÝ, Labyrint světa..., s. 390.

43 KOMENSKÝ, Labyrint světa..., s. 375-376. 
a štěstí. Radost z Boha je zde spojena s láskou jako takovou, napomáhá ke světle mysli, k zahradě rozkoší, již zmiňovanému hortus deliciarum a k libosti ducha (jucunditas animi). Vrcholem lidské moudrosti je trvalé světlo mysli, které je nedílně spojeno s trvale radostným srdcem (suavitates cordis perpetuae).

S tímto trvale radostným srdcem máme ve svých životech přijímat všechno, s čím se setkáváme. Slovy Komenského z úvodu tohoto článku: stát v losu svém až do skonání svého. Toto téměř „zapomenuté, a přitom tolik podstatné a inspirující poselství z díla a myšlení J. A. Komenského jsem chtěla připomenout a přiblížit ve svém článku.

\section{Kontakt}

doc. PaedDr. Miriam Prokešová, Ph.D.

Ostravská univerzita

Pedagogická fakulta

Katedra pedagogiky a andragogiky

Fráni Šrámka 1121/3, 70900 Ostrava - Mariánské Hory

Miriam.Prokesova@osu.cz 